\title{
UPAYA MEWUJUDKAN MUTU PENDIDIKAN MELALUI PARTISIPASI ORANGTUA SISWA
}

\author{
Raden Bambang Sumarsono \\ Universitas Negeri Malang, Jl. Semarang 5 Malang 65145 \\ e-mail: raden.bambang.fip@um.ac.id
}

\begin{abstract}
The Efforts of Actualizing Education Qualities through Students' Parents' Participation. This study aims to find out (1) various forms of parental participation in improving the quality of education, (2) school strategies in empowering parents to participate in improving the quality of education, and (3) indicators of educational quality achievement which is a contribution of parental participation. Methods of this research are qualitative, phenomenological approach, with multi case design study in two public and private elementary schools. Data collection was done by using in-depth interview technique, participant observation, and documentation study. Data analysis technique with flow model and comparative constant. There are three formulation of research results, namely: (1) parent participation in improving the quality of education in the form of physical and non-physical; (2) school strategies in empowering parents to participate in improving the quality of education through the creation of exciting and beneficial programs for parents, creating a conducive climate, parental involvement from planning to evaluation of school programs, transparency and accountability principles, through the intensity of communication through various communication media; and (3) indicators of educational quality attainment which is a contribution of parental participation covering non-academic achievement achievement through extracurricular activities, learning process, and school conditions.
\end{abstract}

Keywords: parent participation, quality of education, primary school

\begin{abstract}
Abstrak: Upaya Mewujudkan Mutu Pendidikan Melalui Partisipasi Orangtua Siswa. Penelitian ini bertujuan untuk mengetahui (1) ragam bentuk partisipasi orangtua dalam meningkatkan mutu pendidikan, (2) strategi sekolah dalam memberdayaan orangtua untuk berpartisipasi dalam meningkatkan mutu pendidikan, dan (3) indikator pencapaian mutu pendidikan yang merupakan kontribusi dari partisipasi orangtua. Metode penelitian ini adalah kualitatif, pendekatan fenomenologis, dengan rancangan studi multi kasus pada dua sekolah dasar negeri dan swasta. Pengumpulan data dilakukan dengan menggunakan teknik wawancara mendalam, observasi peran serta, dan studi dokumentasi. Teknik analisis data dengan model alir dan comparative constant. Ada tiga rumusan hasil penelitian, yaitu: (1) partisipasi orangtua dalam meningkatkan mutu pendidikan berbentuk fisik dan non-fisik; (2) strategi sekolah dalam memberdayakan orangtua untuk berpartisipasi dalam meningkatkan mutu pendidikan melalui pembuatan program yang menarik dan bermanfaat bagi orangtua, menciptakan iklim yang kondusif, pelibatan orangtua dari perencanaan sampai pada evaluasi program sekolah, penerapan prinsip transparan dan akutabilitas, berikutnya melalui intensitas jalinan komunikasi melalui berbagai media komunikasi; dan (3) indikator pencapaian mutu pendidikan yang merupakan kontribusi dari partisipasi orangtua meliput icapaian prestasi non-akademik melalui kegiatan ekstrakurikuler, proses pembelajaran, dan kondisi sekolah.
\end{abstract}

Kata kunci: partisipasi orangtua, mutu pendidikan, sekolah dasar

Sekolah Dasar (SD) dikatakan manakala mampu memfungsikan seluruh komponen sekolah secara efektif dan efisien dalam rangka mewujudkan pembelajaran yang kondusif sehingga tujuan pendidikan tercapai. Pendidikan di SD merupakan landasan atau pondasi utama yang perlu mendapat perhatian dengan sungguh-sungguh, artinya untuk mendapatkan mutu pendidikan yang lebih tinggi, haruslah diawali dengan penciptaan dan pembentukan SD yang bermutu. Hal ini sesuai dengan pendapat yang dikemukakan oleh Tilaar (2009), bahwa pendidikan sekolah dasar yang bermutu akan terbentuknya 
suatu pendidikan selanjutnya (SLTP, SLTA, dan PT) yang kokoh dan bermutu.

Sangat disadari bahwa secara nasional, pendidikan bermutu masih menjadi masalah krusial di negara ini. Masalah mutu pendidikan memang masih menjadi persoalan utama. Perbaikan mutu yang hampir menjadi program setiap menteri yang duduk di Kementerian Pendidikan dan Kebudayaan, tapi sampai sekarang belum tuntas. Mutu pendidikan belum terangkat dan duduk sejajar dengan negaranegara lain, paling tidak semestinya di Asia Tenggara atau Asia (Soetopo, 2012:3). Permasalahan dan tantangan mutu pendidikan memperlihatkan bagaimana pengelolaan pendidikan membutuhkan pola penanganan yang serius serta secara sistematis dan pengkondisian yang matang. Padahal kondisi tata kelola pendidikan saat ini yang kurang meyakinkan, dan membutuhkan kerja keras untuk dapat keluar dari permasalah-permasalah yang ada (Soetopo, 2012:3).

Mutu pendidikan tidak akan berhasil secara maksimal, tanpa adanya dukungan dari masyarakat (dalam hal ini orangtua peserta didik). Dalam Undang-Undang Republik Indonesia Nomor 20 Tahun 2003 tentang Sistem Pendidikan Nasional disebutkan beberapa peran yang dapat dilakukan oleh masyarakat dalam penyelenggaraan pendidikan, yang diatur dalam Pasal 54 Ayat (1) dan (2), yang berbunyi:

(1) Peranserta masyarakat dalam pendidikan meliputi peran serta perorangan, kelompok, keluarga, organisasi profesi, pengusaha, dan organisasi kemasyarakatan dalam penyelenggaraan dan pengendalian mutu pelayanan pendidikan.

(2) Masyarakat dapat berperan serta sebagai nara sumber, pelaksana, dan pengguna hasil pendidikan.

Sekolah atau madrasah sebagai sebuah lembaga tempat penyemaian ilmu yang terorganisasi secara formal, sangat berperan penting dalam meningkatkan kualitas dan jati diri seseorang, mengubah latar belakang seseorang menjadi lebih baik, sekolah yang baik tidak hanya mengubah anak didiknya menjadi pribadi yang berpendidikan akan tetapi juga turut mengubah lingkungan bermasyarakat menjadi yang lebih baik. Menciptakan sekolah bermutu merupakan suatu proses yang membutuhkan komitmen dan kerjasama yang kuat dari seluruh stakeholders sekolah (Rugaiyah, 2012:455). Jalinan kerja sama antara sekolah dan orangtua yang harmonis akan membawa sekolah ke arah pencapaiaan mutu.

Sekolah dan orangtua memiliki hubungan yang sangat erat dalam mencapai tujuan sekolah atau pendidikan secara efektif dan efisien. Selanjutnya sekolah juga harus menunjang pencapaian tujuan atau pemenuhan kebutuhan orangtua, khususnya kebutuhan akan pendidikan anaknya. Wiyono (2010) menjelaskan, bahwa proses penyelenggaraan pendidikan di sekolah, akan bisa berhasil secara optimal, bila didukung oleh beberapa pihak, baik sumber daya yang berasal dari sekolah, orangtua siswa, maupun masyarakat. Lebih lanjut Wiyono (2010) mengemukakan bahwa partisipasi orangtua siswa baik dalam bentuk material, moral maupun spiritual sangat diperlukan guna mencapai keberhasilan pendidikan di sekolah.

Oleh karena itu, sekolah berkewajiban memberi penjelasan tentang tujuan-tujuan, programprogram, kebutuhan, dan keadaan sekolah kepada orangtua. Sebaliknya, sekolah juga harus mengetahui secara jelas apa yang menjadi kebutuhan, harapan, cita-cita, dan tuntutan orangtua, terutama terhadap sekolah. Mereka (para orangtua) diberi kesempatan untuk berperan dalam program sekolah demi tercapainya visi dan misi. Dengan demikian antara sekolah dan orangtua harus dibina dan dikembangkan suatu hubungan yang harmonis untuk mewujudkan pendidikan yang bermutu. Hasil penelitian yang dilaporkan oleh Murillo (2002) mengungkapkan bahwa keterlibatan orangtua sangat penting untuk meningkatkan kualitas pendidikan di sekolah. Kimaro dan Machumu (2015) melalui hasil penelitiannya melaporkan, bahwa ada hubungan positif dan signifikan antara keterlibatan orangtua dalam aktivitas sekolah anak-anak mereka dan prestasi akademik mereka. Castro et al. (2015) dari hasil kajiannya mengungkapkan bahwa keterlibatan orangtua akan membawa pada pencapaian prestasi akademik anak di sekolah. Berdasarkan pemaparan tersebut, peneliti tertarik untuk melakukan kajian lebih lanjut tentang partisipasi orangtua siswa dalam meningkatkan mutu pendidikan di sekolah dasar dan madrasah ibtidaiyah.

Tujuan utama penelitian adalah untuk memerikan partisipasi orangtua dalam meningkatkan mutu pendidikan di SD. Secara rinci, tujuan penelitian ini adalah untuk memerikan: (1) ragam bentuk partisipasi orangtua dalam meningkatkan mutu pendidikan, (2) strategi sekolah dalam memberdayaan orangtua untuk berpartisipasi dalam meningkatkan mutu pendidikan, dan (3) indikator pencapaian mutu pendidikan yang merupakan kontribusi dari partisipasi orangtua.

\section{METODE}

Penelitian ini dilakukan di Sekolah Dasar (SD) Negeri Kauman 1 dan SD Laboratorium Universitas 
Negeri Malang, Kota Malang Provinsi Jawa Timur. Adapun metode penelitian yang dipergunakan adalah kualitatif. Alasan atau pertimbangan dalam penggunaan metode kualitatif adalah: (1) penelitian kualitatif lebih bersifat naturalistik dan holistik (menyeluruh) dalam menganalisis suatu fenomena; dan (2) penelitian jenis ini lebih peka dalam menangkap informasi kualitatif deskriptif, dengan cara mempertahankan keutuhan subyek yang diteliti.

Rancangan yang dipergunakan dalam penelitian ini adalah studi multi kasus (multi case studies). Hal ini sesuai dengan pendapat Bogdan dan Biklen (2007), bahwa ketika peneliti mengkaji dua atau lebih subyek, latar, atau tempat penyimpanan data, maka apa yang dilakukan tersebut adalah studi multi kasus. Sementara itu, teknik yang dipergunakan dalam penelitian ini adalah studi kasus perbandingan (comparative case studies) yang direkomendasikan oleh Bogdan dan Biklen (2007). Peneliti membandingkan dan mengkontraskan temuan-temuan pada masing-masing kasus individual, dan kemudian menyusun temuan, dan teori substantive lintas kasus sebagai temuan akhir sebagaimana disarankan oleh Bogdan dan Biklen (2007), dan Yin (2002).

Pendekatan penelitian yang dipergunakan adalah fenomenologis, ialah suatu pendekatan yang tidak sekadar menelaah fakta-fakta sosial yang tampak, melainkan bermaksud untuk mengungkap makna di balik fakta sosial yang tampak. Sebab, setiap fakta sosial, senantiasa mempunyai maka (meaning) tertentu. Bahkan mereka yang terlibat dalam interaksi sosial, senantiasa menyadarkan tindakantindakannya pada suatu makna. Makna dibalik fakta sosial yang tampak dan bermaksud untuk ditemukan, didasarkan atas perspektif suyek penelitian sendiri (Bogdan \& Biklen, 2007).

Pengumpulan data merupakan tahap penting dalam penelitian karena perolehan data yang diperoleh di lapangan akan digunakan dalam menganalisis hasil penelitian. Ada beberapa teknik yang digunakan oleh peneliti dalam penelitian ini, yaitu wawancara mendalam, observasi peran serta, dan studi dokumentasi. Analisis data pada kasus individual dengan menggunakan model alir, sebagaimana disarankan oleh Miles, Huberman, dan Saldana (2014) yaitu melalui data reduction, data display, dan conclusions drawing/verifying. Analisis data lintas kasus mengacu pada metode yang direkomendasikan oleh Yin (2002). Keabsahan data dinyatakan dengan credibility, transferability, dependability, dan confirmability.

\section{HASIL DAN PEMBAHASAN}

\section{Ragam Bentuk Partisipasi Orangtua dalam Meningkatkan Mutu Pendidikan}

Berdasarkan hasil analisis lintas kasus tentang ragam bentuk partisipasi orangtua dalam meningkatkan mutu pendidikan di SDN Kauman 1 dan SD Laboratorium, disusun temuan penelitian sebagai berikut.

(1) Partisipasi Orangtua dalam Bentuk Fisik

Aktifitas partisiasi orangtua dalam bentuk fisik meliputi berupa tenaga yaitu pada kegiatan field trip, sumbangan pembangunan gedung sekolah, menumbuhkan nilai-nilai ketaqwaan dan semangat beribadah kepada para siswa melalui kegiatan gema dzulhijah dan gema ramadhan, membantu pengadaan sarana dan prasarana penujang pembelajaran, dan penggalangan pendanaan pendidikan, yang dilakukan secara optimal untuk peningkatan mutu pendidikan.

(2) Partisipasi Orangtua dalam Bentuk Non-Fisik Aktivitas partisipasi orangtua dalam bentuk non-fisik berupa sebagai nara sumber pada kegiatan parenting day; memberikan ide, gagasan, saran ataupun kritikan baik melalui komite, paguyuban bahkan secara individu terhadap pelaksanaan kegiatan program sekolah; melalui komite dan paguyuban membantu dalam penyusunan program sekolah, melakukan koordinasi dalam meralisasikan program, dan mengevaluasi pelaksanaan program, sehingga membantu dalam upaya meningkatkan mutu pendidikan.

Keseluruhan temuan lintas kasus tentang bentuk partisipasi orangtua dalam meningkatkan mutu pendidikan, berikut dikedepankan dalam sebuah matrik tentang temuan bentuk partisipasi orangtua, pada Gambar 1.

Partisipasi orangtua siswa dalam konteks pendidikan merupakan salah satu bentuk kerja sama yang dilaksanakan sekolah dengan orangtua siswa. Partisipasi orangtua dalam meningkatkan mutu pendidikan diimplemetasikan dalam bentuk fisik dan non-fisik. Bentuk partisipasi orangtua dalam meningkatkan mutu pendidikan berupa fisik berkaitan dengan penggalangan pendanaan pendidikan dan keterlibatan secara fisik pada pelaksanaan program kegiatan sekolah.

Temuan penelitian yang terkait dengan bentuk partisipasi orangtua siswa berupa penggalangan pendanaan pendidikan, meliputi bantuan pembiayaan kegiatan ekstrakurikuler, pembiayaan perlombaan, iuran komite, iuran paguyuban, dan pembiayaan lainnya yang menunjang peningkatan mutu pendi- 
dikan di sekolah. Sementara itu berbentuk pula pemberian sumbangan yang dilakukan orangtua antara lain berkaitan dengan hal-hal seperti: barang atau peralatan, gedung atau ruang belajar, perangkat teknologi informasi, air conditioner, bantuan hewan ternak untuk kegiatan keagamaan, penyediaan sarana transportasi untuk kegiatan siswa, dan kegiatan lomba yang diikuti siswa.

Temuan penelitian ini mendukung pandangan dan pendapat Zamroni (2000) yang menyatakan bentuk partisipasi masyarakat dalam hal ini orangtua siswa terhadap sekolah berkaitan dengan upaya mobilisasi dana dan secara konkrit dalam kontribusi dana, bahan, dan tenaga. Lebih lanjut partisipasi masyarakat (orangtua siswa) juga dapat berupa pemberian bantuan dana pendidikan, pemberian bantuan dalam pengembangan akademik, pemberian bantuan dalam pengembangan non-akademik, dan pemberian bantuan untuk penampilan fisik sekolah (Depdiknas, 2007).

Temuan penelitian yang terkait dengan bentuk partisipasi orangtua siswa berupa keterlibatan secara fisik pada pelaksanaan program kegiatan sekolah, meliputi: menjadi sumber belajar atau narasumber pada proses pembelajaran sesuai dengan keahliannya, terlibat dalam kegiatan family gathering, terlibat dalam jalan santai memperingati hari ulang tahun sekolah, mendampingi anak pada saat kunjungan sekolah ke obyek tertentu, dan kegiatan ekstrakurikuler. Bentuk partisipasi tersebut berlangsung secara insidental dan terjadwal. Adapun yang terlibat dalam kegiatan tersebut meliputi orangtua siswa, paguyuban kelas, dan komite sekolah.

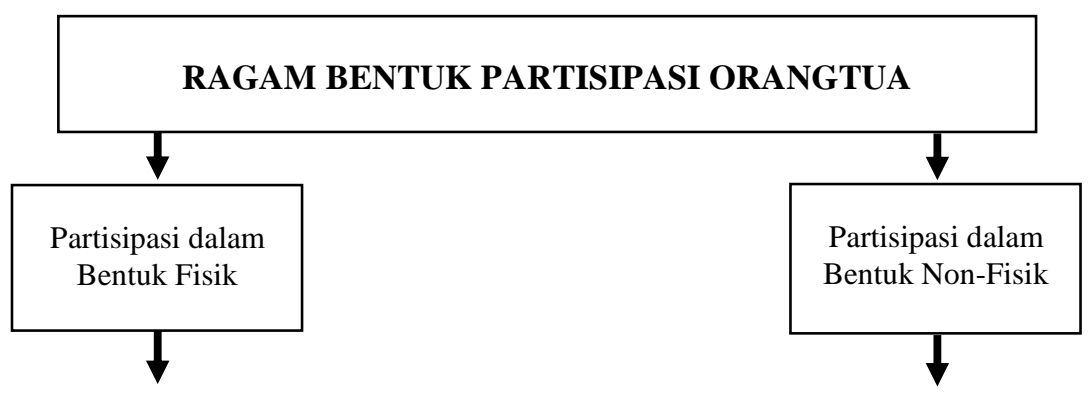

Aktifitas partisiasi orangtua dalam bentuk fisik meliputi:

- berupa tenaga yaitu pada kegiatan field trip,

- sumbangan pembangunan gedung sekolah,

- menumbuhkan nilai-nilai ketaqwaan dan semangat beribadah kepada para siswa

- melalui kegiatan gema dzulhijah dan gema ramadhan,

- membantu pengadaan sarana dan prasarana penujang pembelajaran,

- penggalangan pendanaan pendidikan

Aktivitas partisipasi orangtua dalam bentuk nonfisik meliputi:

- sebagai nara sumber pada kegiatan parenting day;

- memberikan ide, gagasan, saran ataupun kritikan terhadap pelaksanaan kegiatan program sekolah - melalui komite dan paguyuban membantu dalam penyusunan program sekolah, melakukan koordinasi dalam meralisasikan program, dan mengevaluasi pelaksanaan program, sehingga membantu dalam upaya meningkatkan mutu pendidikan.

(1) ketersediaan gedung madrasah dan ruangan belajar yang representatif, (2) ketersediaan sarana penunjang pembelajaran yang memadahi, (3) program kegiatan sekolah berjalan lancar dan mencapai tujuan yang telah ditetapkan,(4) program kegiatan sekolah semakin lebih baik karena disusun dan dievaluasi bersama orangtua, yang dilakukan secara optimal akan meningkatkan mutu pendidikan

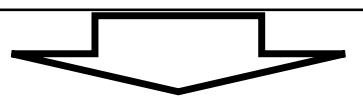

MUTU PENDIDIKAN

Gambar 1. Ragam Bentuk Partisipasi Orangtua dalam Meningkatkan Mutu Pendidikan 
Bentuk partisipasi orangtua menurut Moles (1992) bahwa partisipasi orangtua dalam pendidikan bisa beragam bentuk dan tingkatannya, baik ke dalam maupun ke luar sekolah. Keterlibatan atau partisipasi itu meliputi berbagai kegiatan yang disiapkan dan dibantu oleh sekolah, dan memperkuat partisipasi orangtua dalam pembelajaran dan perkembangan anak mereka. Atau dapat juga dengan membantu guru kelas menjelaskan pokok bahasan tertentu sesuai dengan keahliannya atau keterampilan dan membantu kunjungan sekolah ke obyek tertentu di masyarakat (Reynolds et al., 1996).

Partisipasi masyarakat dalam hal ini orangtua siswa dapat berupa: kesadaran orangtua dalam memikul tanggung jawab pelaksanaan pendidikan dan pemberian bantuan dalam pengembangan akademik (Depdiknas, 2007). Demikian pula menurut Winoto (2007) bahwa partisipasi orangtua siswa di sekolah dapat berkaitan dengan berbagai hal penyelenggaraan program sekolah, misalnya pembelajaran. Hasil penelitian Sumarsono et al. (2016) menyatakan bahwa, partisipasi orangtua dalam meningkatkan mutu sekolah pada aspek pembelajaran, melalui kegiatan parenting day sebagai narasumber, menyiapkan kegiatan field trip, terlibat aktif dalam mengembangkan kelas inspiratif, bersama guru mempersiapkan pelaksanaan try out ujian bagi peserta didik kelas 6, merencanakan dan mengevaluasi kegiatan pembelajaran di luar kelas, dan mempersiapkan alat peraga pembelajaran, sehingga proses dan hasil pembelajaran akan menjadi lebih bermakna dalam upaya meningkatkan mutu pendidikan.

Bentuk partisipasi orangtua dalam meningkatkan mutu pendidikan di sekolah lainnya berupa nonfisik. Bentuk partisipasi orangtua berupa non-fisik berkaitan dengan perencanaan, pelaksanaan, dan evaluasi program sekolah. Hal ini sejalan dengan Undang-Undang Nomor 20 Tahun 2003 tentang Sistem Pendidikan Nasional Pasal 8 yang menyebutkan bahwa masyarakat (dalam hal ini orangtua siswa) berhak untuk berperan serta dalam perencanaan, pelaksanaan, pengawasan dan/atau evaluasi program pendidikan. Sementara itu pada Pasal 9 di sebutkan bahwa masyarakat wajib memberikan dukungan sumber daya dalam penyelenggaraan pendidikan. Hal ini secara tegas mengindikasikan bahwa temuan penelitian ini didukung oleh landasan yuridis.

Partisipasi orangtua yang berkaitan dengan perencanaan program sekolah berupa keikutsertaan orangtua siswa dalam mengidentifikasi kebutuhan sekolah bersama komite dan paguyuban orangtua. Hal ini sejalan dengan Ornstein \& Levine (1985) yang menyatakan, bahwa orangtua siswa dapat di- libatkan dalam merencanakan dan memecahkan permasalahan dalam kurikulum atau program pembelajaran, maupun kebijakan tentang kesiswaan, serta peningkatan program kehumasan. Keterlibatan meraka dapat berbentuk sebagai partner, yaitu dapat membantu mempersiapkan dengan melalui identifikasi segala yang dibutuhkan anak-anak mereka sewaktu akan, selama atau bahkan setelah mengikuti pelajaran di sekolah (Bacharach,1990).

Sekolah bersama orangtua (dalam hal ini komite sekolah) berperan lebih besar dalam perencanaan, pelaksanaan, dan pengawsaan peningkatan mutu pendidikan di sekolah (Suryadi, 2003). Kegiatan tersebut merupakan bentuk dari keterlibatan orangtua sebagai anggota tim pengembang kegiatan sekolah (Aldridge \& Goldman, 2002).

Bentuk partisipasi orangtua dalam peningkatan mutu pendidikan di sekolah yang bersifat nonfisik berikutnya adalah keterlibatan orangtua dalam kegiatan pelaksanaan program sekolah. Partisipasi orangtua teraktualisasikan dalam bentuk memberikan buah pikiran atau gagasan-gagasan dalam pelaksanaan program, dan mengkritisi program beserta implementasinya.

Temuan penelitian tersebut sejalan dengan Peraturan Menteri Pendidikan dan Kebudayaan Nomor 75 Tahun 2016 tentang Komite Sekolah, pada Pasal 3 Ayat (1) butir (b) disebutkan bahwa komite sekolah bertugas untuk menggalang dana dan sumber daya pendidikan lainnya dari masyarakat baik perorangan/oraganisai/dunia usaha/dunia industri maupun pemangku kepentingan lainnya melalui upaya kreatif dan inovatif. Sementara itu Imron \& Sumarsono (2017) mengemukakan bahwa partisipasi masyarakat dalam hal ini orangtua dapat berbentuk partisipasi buah pikiran.

Orangtua turut serta dalam mengawasi dan/ atau mengevaluasi program sekolah sebagai bentuk partisipasi dalam rangka peningkatan mutu pendidikan di sekolah. Kegiatan yang sering dilakukan pada akhir tahun pelajaran dan juga insidental ini ditujukan pada bidang kegiatan seperti: pelaksanaan anggaran sekolah, pelaksanaan kegiatan ekstrakurikuler, kondisi ruang kelas, pelaksanaan proses pembelajaran baik in class maupun out class, dan kegiatan lainnya dalam rangkan penyelenggaraan program sekolah.

Hasil penelitian tersebut sejalan dengan Peraturan Menteri Pendidikan dan Kebudayaan Nomor 75 Tahun 2016 tentang Komite Sekolah Pasal 3 Ayat (1) disebutkan bahwa dalam melaksanakan fungsinya, komite sekolah bertugas untuk (a) memberikan pertimbangan dalam penentuan dan pelaksanaan kebijakan pendidikan, (b) menggalan dana 
dan sumber daya pendidikan, (c) mengawasi pelayanan pendidikan di sekolah sesuai dengan ketentuan perundang-undangan, dan (d) menindaklanjuti keluhan, saran, kritik, dan aspirasi dari peserta didik, orangtua/wali, dan masyarakat serta hasil pengamatan komite sekolah atas kinerja sekolah. Oleh karena itu sekolah bersama orangtua baik yang bergabung dalam komite ataupun paguyuban orangtua siswa seharusnya diberi peran yang lebih besar dalam perencanaan, pelaksanaan, dan pengawasan peningkatan mutu pendidikan di sekolah (Suryadi, 2003).

\section{Upaya Sekolah dalam Memberdayakan Partisipasi Orangtua untuk Meningkatkan Mutu Pendidikan}

Dari hasil analisis lintas kasus tentang upaya sekolah dalam memberdayakan partisipasi orangtua untuk meningkatkan mutu pendidikan, disusun temuan penelitian sebagai berikut.

(1) Guna memberdayakan partisipasi orangtua, maka hal yang dilakukan oleh sekolah dan madrasah ialah dengan menyusun dan melaksanakan program kegiatan yang bermanfaat dan bagi siswa serta menarik bagi orangtua untuk berpartisipasi, sehingga mengerucut pada pencapaian mutu pendidikan.

(2) Pada setiap aktifitas pelaksanaan program dengan melibatkan partisipasi orangtua mulai dari perencanaan, koordinasi, sampai pada evaluasi program, baik secara perorangan maupun kelembagaan melalui paguyuban atau komite dalam rangka pencapaian mutu pendidikan.

(3) Intensitas jalinan komunikasi antara sekolah dengan orangtua, paguyuban kelas, dan komite, melalui berbagai teknik dan media, sehingga terjalin

\section{UPAYA SEKOLAH DALAM MEMBERDAYAKAN PARTISIPASI ORANGTUA UNTUK MENINGKATKAN MUTU PENDIDIKAN}

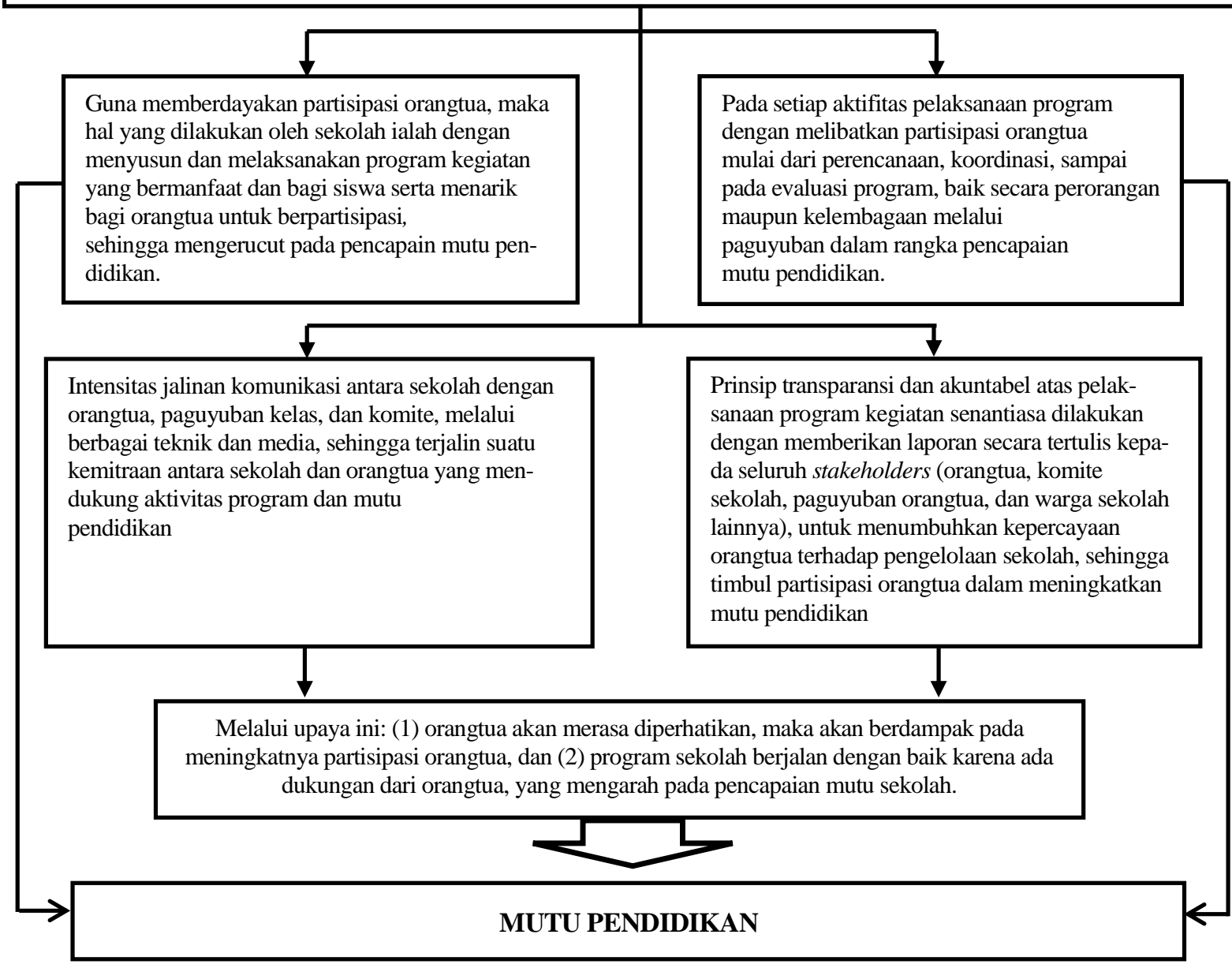

Gambar 2. Upaya Sekolah dalam Memberdayakan Partisipasi Orangtua untuk Meningkatkan Mutu Pendidikan 
suatu kemitraan antara sekolah dan orangtua yang mendukung aktivitas program dan mutu pendidikan.

(4) Prinsip transparansi dan akuntabel atas pelaksanaan program kegiatan senantiasa dilakukan dengan memberikan laporan secara tertulis kepada seluruh stakeholders (orangtua, komite, paguyuban orangtua, dan warga sekolah lainnya), untuk menumbuhkan kepercayaan orangtua terhadap pengelolaan sekolah, sehingga timbul partisipasi orangtua dalam meningkatkan mutu pendidikan.

Berdasarkan keseluruhan temuan lintas tentang upaya sekolah dalam memberdayakan partisipasi orangtua untuk meningkatkan mutu pendidikan, berikut divisualisasikan pada Gambar 2 .

Pendidikan merupakan tanggungjawab bersama antara pemerintah, masyarakat, dan keluarga (orangtua). Anak belajar dan berkembang pada lingkungan keluarga, sekolah, dan masyarakat. Manakala ada keterkaitan yang kuat antara sekolah, keluarga (orangtua), dan masyarakat, serta melibatkan mereka secara aktif membantu usaha pembelajaran dan perkembangan peserta didik, maka hal tersebut akan berdampak positif bagi peningkatan mutu pendidikan. Hasil termuan Herman \& Yeh (1983) menunjukkan bahwa partisipasi orangtua siswa berkorelasi positif terhadap prestasi belajar anak maupun kepuasan orangtua terhadap siswa. Duke \& Canady (1991) menyatakan dalam beberapa penelitian hasilnya sangat meyakinkan bahwa, keterlibatan warga sekolah, termasuk orangtua/wali murid sangat positif mendukung keberhasilan pelaksanaan suatu kebijakan. Keith \& Girling (1991) menegaskan bahwa keterlibatan secara aktif dari orangtua membawa dampak positif bagi peningkatan siswa. Tanpa partisipasi atau dukungan dari orangtua, pendidikan (sekolah) tidak akan berhasil dengan maksimal (Kusmintardjo, 2010).

Orangtua memiliki potensi yang besar dalam membantu sekolah dalam mengembangkan programprogram kegiatan, namun demikian semuanya juga tergantung pada bagaimana cara sekolah dalam mendekati atau memberdayakan potensi orangtua siswa. Temuan penelitian menunjukkan bahwa upaya-upaya yang dilakukan oleh sekolah dalam memberdayakan partisipasi orangtua untuk peningkatan mutu pendidikan di sekolah, meliputi: pembuatan program sekolah yang menarik bagi orangtua, pengelolaan keuangan secara transparan dan penerapan prinsip akuntabilitas dengan memberikan laporan pertanggungjawaban kegiatan kepada orangtua melalui publikasi sekolah, penciptaan iklim yang kondusif bagi orangtua siswa, peningkatan prestasi akademik dan non-akademik, peningkatan kualitas layanan sekolah, intensitas jalinan komunikasi antara sekolah dan orangtua baik secara perorangan maupun secara organisatoris, dan pelibatan orangtua dalam merencanakan, melaksanakan, dan evaluasi program.

Upaya sekolah untuk memberdayakan partisipasi orangtua dalam meningkatkan mutu pendidikan berupa pembuatan program sekolah yang menarik bagi orangtua, diantaranya yaitu: program student day inclass dan outclass, program field trip, outbond, perayaan hari ulang tahun sekolah, dan perayaan hari besar agama/nasional. Dalam upaya memberdayakan partisipasi orangtua atau mengembangkan jalinan kerjasama antara sekolah dan orangtua siswa, maka sekolah perlu memperhatikan prinsip-prinsip, antara lain: (1) program yang dibuat harus mudah dipahami dan dilaksanakan, (2) peka terhadap aspirasi masyarakat dalam hal ini adalah orangtua siswa, dan (3) ide yang terkandung dikomunikasikan secara sederhana dan jelas (Rebore, 1985).

Temuan penelitian selanjutnya berkaitan dengan upaya sekolah untuk memberdayakan partisipasi orangtua dalam meningkatkan mutu pendidikan dengan melalui pengelolaan keuangan secara transparan dan penerapan prinsip akuntabilitas dengan memberikan laporan pertanggungjawaban kegiatan kepada orangtua. Hal-hal yang perlu diperhatikan dalam rangka meningkatkan atau memberdayakan jalinan kerjasama antara sekolah dan masyarakat (orangtua), diantaranya yaitu jujur, terbuka, dan hubungannya bersifat interaktif.

Pemberdayaan partisipasi orangtua dalam meningkatkan mutu pendidikan diupayakan juga melalui penciptaan iklim yang kondusif bagi orangtua siswa. Seluruh warga sekolah (kepala sekolah, guru, staf, dan siswa) harus menciptakan suasana yang kondusif sehingga masyarakat termasuk di dalamnya orangtua akan melihat dan merasakan suasana sekolah yang menyenangkan, dan ini akan meyakinkan para orangtua akan keseriusan sekolah dalam mendidik anak-anak mereka. Bacharach (1990) berpendapat bahwa pengelolaan hubungan masyarakat yang di dalamnya termasuk orangtua, dapat berlangsung dengan efektif manakala sekolah memperhatikan dan mengembangkan prinsip: “...(1) ciptakan sekolah yang terbuka, menolong, dan bersahabat, (2) beri penghargaan kepada mereka (orangtua) yang telah menunjukkan dedikasi dan sumbangsih bagi kemajuan pendidikan di sekolah...".

Upaya memberdayakan partisipasi orangtua sekolah harus dapat membina kerjasama dengan orangtua secara kondusif dan menyenangkan (Suryadi, 2003). Hal yang sama disampaikan Kusmin- 
tardjo (2010) bahwa sikap yang perlu dikembangkan dalam membangun iklim sekolah yang kondusif, antara lain: bersikap ramah, luwes, terbuka, antusias, berempati, sabar, dan menghormati orang lain. Sementara itu Rohiat (2010) menyebut "contoh hal-hal yang dapat memberdayakan partisipasi orangtua, seperti memberikan pujian kepada orangtua, dan perlakuan yang manusiawi..."

Peningkatan capaian prestasi akademik dan non-akademik peserta didik sekolah merupakan salah satu upaya yang dilakukan oleh sekolah dalam memberdayakan partisipasi orangtua. Hasil penelitian Hewison \& Tizard (1980) menunjukkan "adanya suatu hubungan antara keterlibatan orangtua siswa dengan capaian hasil membaca para siswa di sekolah". Temuan lainnya dari Preedy (1993) menunjukkan bahwa "keterlibatan orangtua siswa dalam kegiatan sekolah berpengaruh positif terhadap kemajuan dan perkembangan belajar siswa". Hal ini mengindikasikan bahwa prestasi akademik maupun non-akademik akan semakin meningkat manakala ada partisipasi dari orangtua. Oleh karena itu, mobilisasi atau memberdayakan partisipasi orangtua diharapkan secara sinergis mengarah pada satu tujuan yaitu peningkatan mutu pendidikan.

Temuan penelitian berikutnya tentang upaya memberdayakan partisipasi orangtua yang dilakukan oleh sekolah dalam rangka peningkatan mutu pendidikan dilakukan melalui intensitas jalinan komunikasi antara sekolah dan orangtua baik secara perorangan maupun secara organisatoris. Hubungan sekolah dan orangtua dapat berlangsung dengan efektif, jika sekolah melakukan komunikasi dengan orangtua secara jelas dan sesering mungkin (Bacharach, 1990). Komunikasi merupakan suatu sarana yang paling krusial untuk membangun jalinan kerja sama yang baik dengan orangtua. Karena itu, sekolah harus memberikan waktu yang cukup untuk berkomunikasi secara teratur dengan pihak orangtua (Kusmintardjo, 2010). Ada beberapa hal yang perlu dilakukan oleh sekolah dalam meningkatkan intentitas jalinan komunikasi dengan orangtua siswa, diantaranya yaitu melalui media: surat, website, majalah sekolah, buletin sekolah, telpon/handphone, dan media sosial lainnya seperti whatshap, blackberry massanger, dan line). Hal-hal lain yang bisa dilakukan oleh sekolah dalam memberdayakan partisipasi orangtua siswa dengan melalui komunikasi yang efektif (Rohiat, 2010).

Hasil penelitian Radu (2011) tentang keterlibatan orangtua di sekolah pada 10 negara Eropa Timur menunjukkan, bahwa keterampilan dan strategi komunikasi yang diaplikasikan guru kepada orangtua akan berdampak pada keterlibatan secara aktif dari orangtua pada beberapa kegiatan sekolah. Adanya interaksi atau komunikasi antara orangtua dan pihak sekolah menjadi kunci berlangsungnya proses pendidikan anak yang efektif, baik di sekolah maupun di rumah. Hal ini menunjukkan betapa pentingnya jalinan komunikasi antara sekolah dan orangtua untuk keberlangsungan kemitraan sekolah dan orangtua

Pemberdayaan partisipasi orangtua dengan melalui pelibatan orangtua pada perencanaan, pelaksanaan, dan pengevaluasian program sekolah. Hasil penelitian ini sejalan dengan yang dinyatakan oleh Oernstein \& Levine (1985) bahwa orangtua siswa dapat dilibatkan dalam merencanakan dan memecahkan permasalahan pada bidang kurikulum atau program pembelajaran, kebijakan tentang kesiswaan, serta peningkatan program kehumasan.

Ada hal penting yang perlu diperhatikan oleh sekolah dalam rangka mengembangkan keterlibatan masyarakat (orangtua) dengan sekolah, yaitu: "...partisipasi, artinya program dan layanan yang diberikan sekolah hendaknya disusun bersama-sama..." (Maisyaroh, 2001). Sekolah bersama masyarakat (temasuk orangtua siswa) seharusnya diberi peran yang lebih besar dalam perencanaan, pelaksanaan, dan pengawasan peningkatan mutu pendidikan di sekolah (Suryadi, 2003). Hal senada diungkapkan oleh Rohiat (2010), bahwa peningkatan partisipasi merupakan suatu upaya menciptakan lingkungan yang terbuka dan demokratis dimana guru, siswa, pegawai, dan masyarakat (orangtua siswa) didorong untuk terlibat secara langsung dalam penyelenggaraan pendidikan, mulai dari pengambilan keputusan, pelaksanaan, dan evaluasinya yang diharapkan dapat meningkatkan mutu pendidikan di sekolah.

\section{Indikator Pencapaian Mutu Pendidikan yang Merupakan Kontribusi Partisipasi Orangtua}

Berdasarkan hasil analisis lintas kasus tentang indikator pencapaian mutu pendidikan yang merupakan kontribusi partisipasi orangtua, disusun temuan penelitian sebagai berikut.

(1) Pembinaan terhadap potensi minat dan bakat siswa dikembangkan secara profesional melalui kegiatan ekstrakurikuler yang didukung secara penuh oleh orangtua, sehingga mencapai prestasi di bidang non-akademik.

(2) Peningkatan kompetensi tenaga kependidikan yang dilakukan atas kerjasama dengan komite, sangat terbuka dan dilakukan dengan mendorong mereka menekuni di berbagai aktivitas sehingga menghasilkan prestasi diberbagai bi- 
dang, akan memberikan kontribusi terhadap proses pendidikan yang bermuara pada peningkatan mutu pendidikan.

(3) Memanfaatkan teknologi informasi dalam pelaksanaan proses pembelajaran dengan ketersediaan hot spot area secara gratis, laboratorium komputer, terpasangnya LCD di tiap kelas yang dimanfaatkan guru dalam pembelajaran; dan dengan pembelajaran berwawasan global melalui pendekatan PAKEM, sehingga akan mendukung secara bermutu terhadap aktivitas akademik.

(4) Terdapat beberapa program unggulan yang mengarah kepada pengembangan karakter dan budaya sekolah yang dijabarkan dari visi dan misi, akan mendukung pada pelaksanaan proses kegiatan akademik dan non akademik yang bermuara pada pencapaian mutu pendidikan.

(5) Penyediaan sarana dan prasarana dengan jumlah yang mencukupi, digunakan secara optimal, dan terpelihara secara baik, sehingga senantiasa siap dipergunakan untuk kepentingan pembelajaran atau akademik dan kepentingan lainnya atau non-akademik, akan mendukung pada pencapaian mutu pendidikan.

Keseluruhan temuan lintas kasus tentang indikator pencapaian mutu pendidikan yang merupakan kontribusi partisipasi orangtua, berikut dikedepankan dalam sebuah matrik tentang temuan indikator pencapaian mutu berdasarkan partisipasi orangtua, pada Gambar 3.

Hasil temuan penelitian tentang indikator pencapaian mutu pendidikan yang merupakan kontribusi partisipasi orangtua diketahui bahwa dari ke dua kasus pada dasarnya memiliki persamaan dan ada beberapa yang berlainan satu sama lainnya. Secara keseluruhan indikator pencapaian mutu pendidikan di sekolah dasar ditunjukkan oleh adanya capaian prestasi non-akademik melalui kegiatan ekstrakurikuler, dan kondisi sekolah pada umumnya.

Beragamnya kegiatan ekstrakurikuler yang meliputi; seni, olah raga, pramuka, UKS, baca tulis Al Qur'an, beserta capaian hasil kejuaraan maupun perlombaan. Indikator pencapaian mutu pendidikan yang merupakan kontribusi partisipasi orangtua berikutnya yaitu terkait kondisi sekolah, yang meliputi; pelaksanaan proses pembelajaran yang berbasis teknologi informasi, pembelajaran yang berwawasan global, pembelajaran berpusat pada anak, pembelajaran yang inovatif dan aplikatif, peningkatan kompetensi tenaga pendidik, dan terselenggaranya program-program pembiasaan yang menjadi ikon sekolah yang didukung sepenuhnya oleh para orangtua.

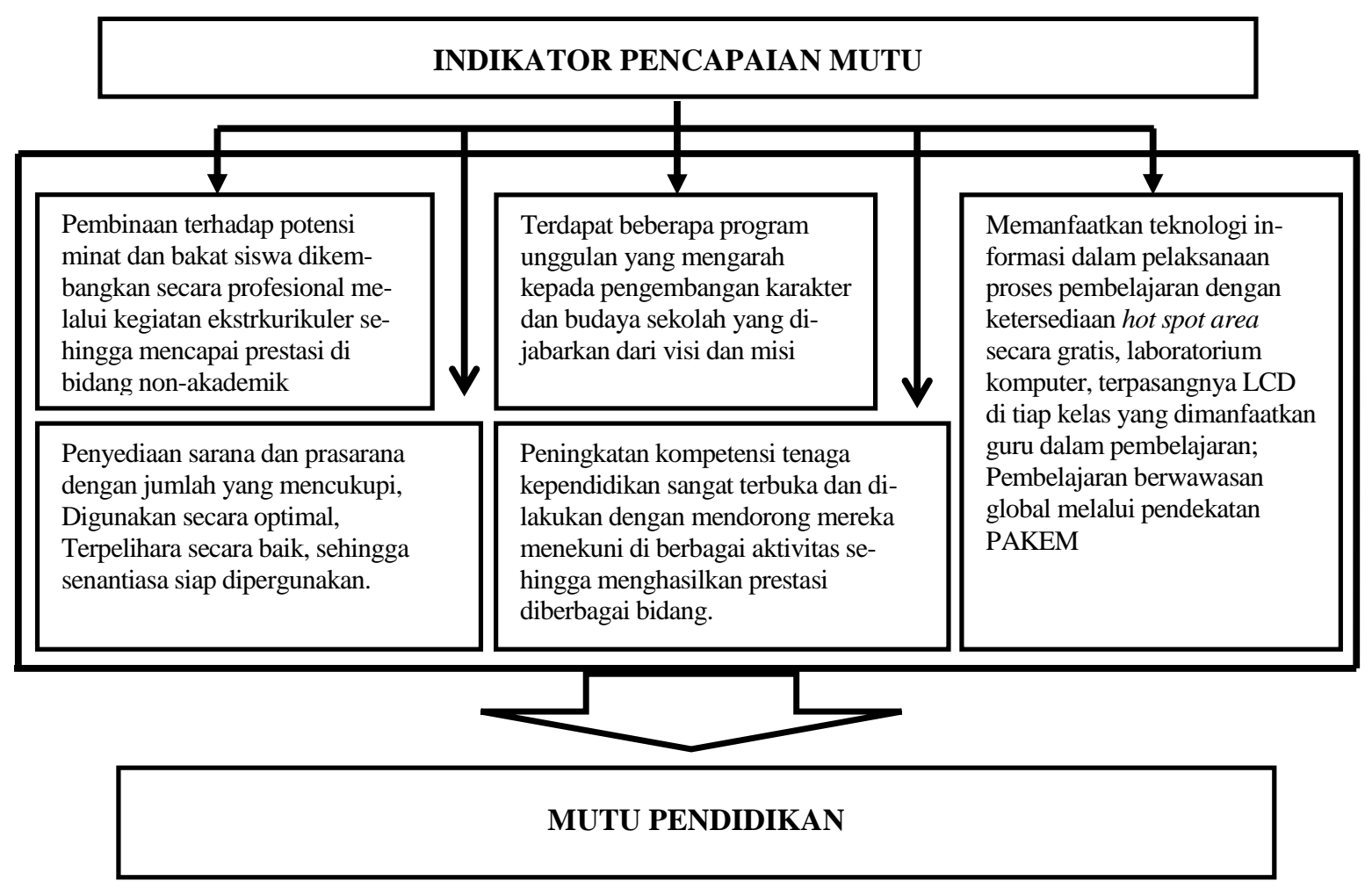

Gambar 3. Indikator Pencapaian Mutu Pendidikan yang Merupakan Kontribusi Partisipasi Orangtua 
Sekolah bermutu meliputi penggunaan teknologi, proses dan fasilitas yang bervariasi; nilai akademik dapat dilihat oleh orangtua, menggunakan pendekatan experiental untuk mencapai hasil yang diinginkan, lulusan yang sehat secara fisik, dan memiliki life skill yang memadahi (Rasheed, 2000). Adapun Hoy et al. (2000) memandang mutu dalam pendidikan merupakan proses pembelajaran yang dapat meningkatkan keinginan pelanggan untuk berprestasi serta dapat mengembangkan bakat mereka, dan dalam waktu yang sama dapat memenuhi standar yang ditetapkan oleh klien. Syafaruddin (2002) berpendapat bahwa karakteristik sekolah yang bermutu adalah dengan adanya hasil belajar yang maksimal, yaitu prestasi yang dapat diukur. Prestasi inilah yang oleh kebanyakan orang dikaitkan dengan mutu. Prestasi ini tidak hanya dikaitkan dalam bidang akademik dan non-akademik saja, namun juga tercermin dalam perilaku dan kepribadian siswa.

Mutu dalam prespektif pendidikan tidak hanya terfokus pada pengembangan prestasi akademis saja, melainkan juga mengembangkan potensi psikis, fisik, etika, moral, religi, emosi, spirit, dan intelegensi (Kholis, 2003). Sementara itu Dagget (2005) menyatakan bahwa karakteristik sekolah yang bermutu adalah komitmen terhadap prestasi yang tinggi; pengembangan pembelajaran dilakukan secara profesional; menghubungkan pengalaman di luar sekolah dalam pembelajaran di dalam kelas; pembelajaran yang fleksibel dan relevan.

Di dalam Peraturan Pemerintah Nomor 19 Tahun 2005 tentang Standar Nasional Pendidikan jo Peraturan Pemerintah Nomor 23 Tahun 2013 tentang perubahan atas Peraturan Pemerintah Nomor 19 Tahun 2005 tentang Standar Nasional Pendidikan, disebutkan dalam hal mutu tenaga pendidik bahwa tenaga pendidik tingkat SD harus memnuhi kualifikasi akademik minimal D-IV atau S-1, dengan latar belakang pendidikan tinggi di bisang pendidikan, serta bersertifikasi profesi guru SD. Adapun dalam standar sarana dan prasarana, untuk menjadi sekolah yang bermutu harus memiliki sarana yang meliputi perabot, peralatan pendidikan, media pendidikan, buku dan sumber belajar lainnya, bahan habis pakai, serta perlengkapan lain yang diperlukan untuk menunjang proses pembelajaran yang teratur dan berkelanjutan. Standar prasarana yang harus dimiliki meliputi: lahan, ruang kelas, ruang pimpinan satuan pendidikan, ruang pendidik, ruang tata usaha, ruang perpustakaan, ruang laboratorium, instalasi daya dan jasa, tempat berolahraga, tempat beribadah, tempat bermain, tempat berkreasi, dan ruang/ tempat lain yang diperlukan untuk menunjang proses pembelajaran yang terarah dan berkelanjutan.

Mutu proses pembelajaran oleh Danim (2006) mengandung makna kemampuan sumberdaya pendidikan dalam mentransformasikan multi jenis masukan dan situasi untuk mencapai derajat nilai lebih tinggi yang dibutuhkan siswa. Hasil pendidikan bermutu jika mampu melahirkan keunggulan akademik dan ekstrakurikuler. Hal senada juga diungkapkan oleh Bafadal (2006), bahwa: sekolah dasar yang bermutu adalah sekolah dasar yang mampu berfungsi sebagai wadah proses edukasi, sosialisasi, dan transformasi, sehingga mampu mengantarkan anak didik menjadi seorang terdidik, memiliki ilmu pengetahuan dan teknologi, termasuk juga kebudayaan bangsa yang membuatnya siap memasuki sekolah selanjutnya yaitu sekolah menengah pertama atau madrasah tsanawiyah.

\section{SIMPULAN}

Berdasarkan keseluruhan temuan lintas kasus dapat dikemukakan bahwa: (1) bentuk partisipasi orangtua dalam meningkatkan mutu pendidikan, meliputi fisik dan nonfisik; (2) upaya memberdayakan partisipasi orangtua dalam meningkatkan mutu pendidikan, ialah dengan menyusun dan melaksanakan program kegiatan sekolah yang bermanfaat bagi siswa dan menarik bagi orangtua untuk berpartisipasi, setiap aktivitas pelaksanaan program sekolah dengan melibatkan orangtua, mengembangkan iklim sekolah yang kondusif bagi terselenggaranya partisipasi orangtua, intensitas jalinan komunikasi dengan orangtua, dan menerapkan prinsip transparansi dan akuntabilitas; dan (3) indikator pencapaian mutu pendidikan yang merupakan kontribusi dari partisipasi orangtua, meliputi capaian prestasi nonakademik melalui kegiatan pengembangan minat dan bakat siswa melalui kegiatan ekstrakurikuler dan keikutsertaan dalam berbagai perlombaan yang didukung oleh orangtua, terdapat program-program unggulan dari masing-masing sekolah dasar dan mendapat dukungan penuh dari orangtua, pembelajaran berbasis teknologi informasi, dan sarana prasarana sekolah hasil dari sumbangan orangtua yang dikelola dengan baik sehingga siap untuk digunakan untuk menunjang proses pembelajaran.

Partisipasi orangtua dengan beragamnya bentuk, disertai dengan upaya untuk memberdayakan partisipasi orangtua kearah lebih baik lagi, yang mengerucut pada capaian indikator peningkatan mutu pendidikan, maka akan tercapai mutu pendidikan. 


\section{DAFTAR RUJUKAN}

Aldridge, J. \& Goldman, R. 2002. Current Issues and Trends in Education. Boston: Allyn and Bacon.

Bacharach. S.B. 1990. Education Reform: Making Sense of It All. Boston: Allyn and Bacon.

Bafadal, I. 2006. Manajemen Peningkatan Mutu Sekolah Dasar dari Sentralisasi Menuјu Desentralisasi. Jakarta: Bumi Aksara.

Bogdan, R.C. \& Biklen, S.K. 2007. Qualitatif Research for Education (An Introduction to Theories and Methods) $5^{\text {th }}$ Edition. Boston: Allyn \& bacon, Inc.

Castro, M., Casas, E., Martin, E., Lizasoain, L., Asencio, E., \& Gaviria, J. 2015. Parental Involvement on Student Academic Achievemnt: A Meta-Analysis. Education Research Review, 14: 33-46.

Dagett, W.R. 2005. Successful School: From Research to Action Plan. (Online). (http://www.quality. cr.k12.ia.us/Resources/SuccessfulSchools_Daggett _05.pdf), diakses 15 Februari 2017.

Danim, S. 2006. Visi Baru Manajemen Sekolah. Jakarta: Bumi Aksara.

Depertemen Pendidikan Nasional. 2007. Pendidikan dan Pelatihan: Manajemen Hubungan Masyarakat dalam Pemberdayaan Masyarakat. Jakarta: Ditnaga Ditjen PMPTK.

Duke, L.D. \& Canady, R.L. 1991. School Policy. New York: McGraw Hill Inc.

Herman, J.L. \& Yeh, J.P. 1983. Some Effective of Parent Involment in School. Urban Review, 15 (1): $11-16$.

Hewison, J. \& Tizard, J. 1980. Parental Involvement and Reading Attainment. Brithis Journal of Education Psychology, 50, (3): 209-215

Hoy, C., Bayne-Jardine, C., \& Wood, M. 2000. Improving Quality in Education. London: Falmer Press.

Imron, A. \& Sumarsono, R.B. 2017. Manajemen Hubungan dan Partisipasi Masyarakat di Sekolah. Malang: UM Press.

Keith, S. \& Girling, R. H. 1991. Educational, Management, and Participation: New Directions in Educational Administration. Boston: Allyn and Bacon.

Kholis, N. 2003. Sekolah Unggulan yang tidak Unggul. (Online). (http://www.researchengine.com/nurcholis/html). Diakses 15 Februari 2017.

Kimaro, A.R. \& Machumu, H.J. 2015. Impacts of Parental Involvement in School Activities on Academic Achievement of Primary School Children. International Journal of Education and Research, 3 (8): 483-494.

Kusmintardjo. 2010. Manajemen Keterlibatan Orang Tua dalam Pendidikan. Manajemen Pendidikan, 23 (2): 195-203.

Maisyaroh. 2001. Melaksanakan Peranserta Masyarakat dalam Penyelenggaraan Lembaga Pendidikan, Suatu Kajian Menyongsong Otonomi Pendidikan. Jurnal Manajemen Pendidikan, 14 (2): 10-17.
Milles, M.B., Huberman, M.A. \& Saldana, J. 2014. Qualitative Data Analysis: A Methods Sourcebook. Thousand Oaks, California: Sage.

Moles, O. 1992. Synthesis or Recent Research on Parent Participation on Children's Education. Educational Leadership, 44.

Murillo, I.I. 2002. Good Effective School Improvement in Spain. Educational Research and Evaluation, 8 (4): $387-410$.

Orrstein, A.C. \& Levine, D.U. 1985. An Inttroducting to The Foundations of Education. Boston: Houghton Mifflin Company.

Peraturan Menteri Pendidikan dan Kebudayaan Republik Indonesia Nomor 75 Tahun 2016 tentang Komite Sekolah.

Peraturan Pemerintah Nomor 19 Tahun 2005 Tentang Standar Nasional Pendidikan. Bandung: Citra Umbara.

Preedy, M. (Ed). 1993. Managing The Effective School. London: The Open University.

Radu, B.M. 2011. Parental Involvement: in School: A Study of Resources, Mobilization, and in Herent Inequality. Journal of Comparative Research in Anthropology and Sociaology, 2 (2): 103-115.

Rasheed, S. 2000. Defining Quality in Education. New York, USA: United Nations Childrent's Fund. (Online). (http://www.qualityeducation.org). Diakses 10 Maret 2015.

Rebore, R.W. 1985. Educational Administration: AManagement Approach. Enliwood Cliff, New Jersey: Prentice-Hall Inc.

Reynolds, D., Bollen, R., Creemers, B., Hop[kins, D., Stoll, L. \& Lagerwejj, N. 1996. Making Good Schools: Linking Schools Effectiveness and School Improvement. London: Routledge.

Rohiat. 2010. Manajemen Sekolah: Teori Dasar dan Praktik. Bandung: PT. Rafika Aditama.

Rugaiyah. 2012. Pengembangan Komptensi Kepala Sekolah dalam Meningkatkan Mutu Pendidikan. Artikel dalam Prosiding International Conference Educational Management, Administration and Leadership. Malang: Jurusan Administrasi Pendidikan.

Soetopo, H. 2012. Tantangan dan Isu-Isu Pendidikan Nasional Serta Solusinya. Artikel dalam Prosiding International Conference Educational Management, Administration and Leadership. Malang: Jurusan Administrasi Pendidikan.

Sumarsono, R.B., Imron, A., Wiyono, B.B., \& Arifin, I. 2016. Parents Participation In Improving The Quality Of Elementary School In The City Of Malang, East Java, Indonesia. International Education Studies, 9 (10): 256-262.

Suryadi, A. 2003. Dewan Pendidikan dan Komite Sekolah Mewujudkan Sekolah-Sekolah yang Mandiri dan Otonom, (Online). (http://www.dep- 
diknas.go.id.serba-serbidpks/pemberdayaandpks/html). Diakses 10 Maret 2015.

Syafaruddin. 2002. Manajemen Mutu Terpadu dalam Pendidikan, Konsep, Strategi, dan Aplikasi. Jakarta: Grasindo.

Tilaar, H.A.R. 2009. Membenahi Pendidikan Nasional. Jakarta: Rineka Cipta.

Undang-Undang Nomor 20 Tahun 2003 tentang Sistem Pendidikan Nasional. Bandung: Citra Umbara.

Winoto, S. 2007. Komite Sekolah dalam Proses Manajemen Peningkatan Mutu Pendidikan (Studi Mul- tikasus di SMP Nusa bangsa Malang dan MTs Harapan Bangsa Malang). Disertasi tidak diterbitkan. Malang: Program Pascasarjana Universitas Negeri Malang.

Wiyono, B.B. 2010. Partisipasi Masyarakat terhadap Pelaksanaan Kegiatan Pendidikan. Manajemen Pendidikan Volume, 23 (1): 10-11.

Yin, R.K. 2002. Case Study Research: Design and Methods. Thousand Oaks, CA: Sage.

Zamroni. 2000. Paradigma Pendidikan Masa Depan. Yogyakarta: Biptaf Publishing. 